\author{
E. Di Gristina, G. Domina \& A. Geraci
}

\title{
Karyological data of three Hieracium (Asteraceae) from Sicily and South Italy
}

\begin{abstract}
Di Gristina, E., Domina, G. \& Geraci, A. 2021: Karyological data of three Hieracium (Asteraceae) from Sicily and South Italy [In Kamari, G., Blanché, C. \& SiljakYakovlev, S. (eds), Mediterranean plant karyological data-31]. - Fl. Medit. 31: 336340. http://dx.doi.org/10.7320/FlMedit31.336

Chromosome numbers are given for three endemic Hieracium taxa from Sicily and Campania (Southern Italy). All the examined taxa resulted triploid $(2 n=3 \mathrm{x}=27)$. The triploid chromosome set found in the population of $H$. pallidum from Rocche dell'Argimusco (Peloritani Mountains, NE-Sicily) differs from the previous counts $(2 n=4 \mathrm{x}=36)$ reported for the same species from its locus classicus (Mt. Etna).
\end{abstract}

Keywords: Agamospermy, chromosome number, endemism, polyploidy, distribution, rediscovery.

\section{Introduction}

The genus Hieracium L. s. str. (Asteraceae) is well known as one of the most speciesrich plant group in the world. It includes perennial herbs distributed predominantly in temperate regions of Europe, Asia and North America (Chrtek \& al. 2006). In the past, Hieracium also included Pilosella Vaill. but now they are treated as two separate genera, based on a whole range of morphological, biochemical, cytological and genetical characteristics (Braütigam \& Greuter 2007; Di Gristina \& al. 2013). Hieracium belongs to a group of genera in which diplosporous agamospermy and polyploidy seem to prevail. Hybridization also appears as a very rare phenomenon and is most likely confined to crosses between diploid sexual species (Chrtek $\&$ al. 2006). The primitive basic chromosome number for most of the Asteraceae and especially for Hieracium is $\mathrm{x}=9$ (Babcock 1947). However, the great majority of Hieracium taxa are triploid $(2 n=27)$ or tetraploid $(2 n=36)$ due to the species being sexual or apomictic or both (Mraz \& al. 2001; Niketic \& al. 2003). Sexuality is extremely rare and confined to a few diploid species, mostly distributed in South Europe (Merxmüller 1975; Chrtek \& al. 2004). Agamospermy, together with sexuality and hybridization, in the past have given rise to a very large number of variants that have been described as subspecies, as has traditionally been the case in Central Europe or at rank of species in British Isles, Scandinavia, East Europe (Mraz \& al. 2001; Chrtek \& al. 2006). 
In order to define the phylogenetic and systematic relationships among the endemic Hieracium taxa in Southern Italy, a cytogeographical analyses at population level, is in progress. In this frame, we here report the chromosome number of two Hieracium from Sicily and one from Campania.

1997. Hieracium hypochoeroides subsp. lucanicum (Arv.-Touv.) Di Grist., Gottschl. \& Raimondo $-2 n=3 \mathrm{x}=27$ (Fig. 1a).

It: Salerno, Parco Nazionale del Cilento e Vallo di Diano, Mt. Sacro, $40^{\circ} 12^{\prime}$ 56,88' N, $15^{\circ} 20^{\prime} 08,8^{\prime \prime} \mathrm{E}$, granitic conglomerate and sandstone rocks, $1.655 \mathrm{~m}$ a.s.1., $06 \mathrm{Jul}$ 2013, E. Di Gristina s.n. (PAL).

Hieracium hypochoeroides subsp. lucanicum (Arv.-Touv.) Di Grist., Gottschl. \& Raimondo is a little known taxon described from Mt. Sacro (Parco Nazionale del Cilento e Vallo di Diano, South Italy). It is a rosulate hemicryptophyte published by Guadagno under H. sartorianum var. lucanicum Arv.-Touv. and recently reclassified as a subspecies of H. hypochoeroides (Di Gristina \& al. 2015a). The collective species H. hypochoeroides s.l. is a young aggregate of many apomictic microtaxa which have evolved probably during the post-glacial period (Di Gristina \& al. 2015b). Many of the taxa described so far have a very restricted distribution and are very narrow endemics (Di Gristina \& al. 2015b). In southern Europe there are only local populations and most of them seem to be relict (Di Gristina \& al. 2016a).

The chromosome number $2 n=3 \mathrm{x}=27$ (Fig. 1a), found here for the first time on material from its locus classicus (Mt. Sacro, Salerno) is included in the variability ( $2 n$ $=3 \mathrm{x}=27,2 n=4 \mathrm{x}=36$ ) reported for the collective species $H$. hypochoeroides by Sell \& West (1976).

1998. Hieracium pallidum Biv. $-2 n=3 x=27$ (Fig. 1b).

Si: Messina, Peloritani Mountains, Rocche dell'Argimusco, $37^{\circ} 59^{\prime} 19,70^{\prime \prime} \mathrm{N}, 15^{\circ} 02^{\prime}$ 26,24” E, quartzarenitic rocks, 1.225 m a.s.1., 17 Jun 2012, E. Di Gristina s.n. (PAL).

Hieracium pallidum Biv. is a rosulate chasmophyte recently considered as an intermediate species between $H$. schmidtii and $H$. racemosum ("schmidtii > racemosum") (Gottschlich \& al. 2013). It was included as a local endemic species of Sicily in $H$. sect. Grovesiana which comprehends a complex of similar morphotypes resulting from hybridization processes of $H$. grovesianum Belli and H. racemosum Willd. (Di Gristina \& al. 2014a). Other records given for $H$. pallidum from various European countries and regions belong to other subspecies of $H$. schmidtii complex, and need a critical revision (Gottschlich \& al. 2013). In Sicily, H. pallidum has so far been known only from Mt. Etna (E-Sicily). A new population has recently been discovered from Rocche dell'Argimusco (Peloritani Mountains, NE-Sicily). 
The chromosome number $2 n=3 x=27$ (Fig. 1b), found here on material from Rocche dell'Argimusco does not agree with the number reported for the same species $(2 n=4 \mathrm{x}=$ 36) from the locus classicus (Mt. Etna) by Brullo \& al. (2005) and Di Gristina \& al. (2005); it also differs with that detected for $H$. pallidum subsp. aetnense $(2 n=4 \mathrm{x}=36)$ (Di Gristina $\&$ al. 2014b). These observations suggest that the $H$. pallidum population of Rocche dell'Argimusco needs critical treatment.

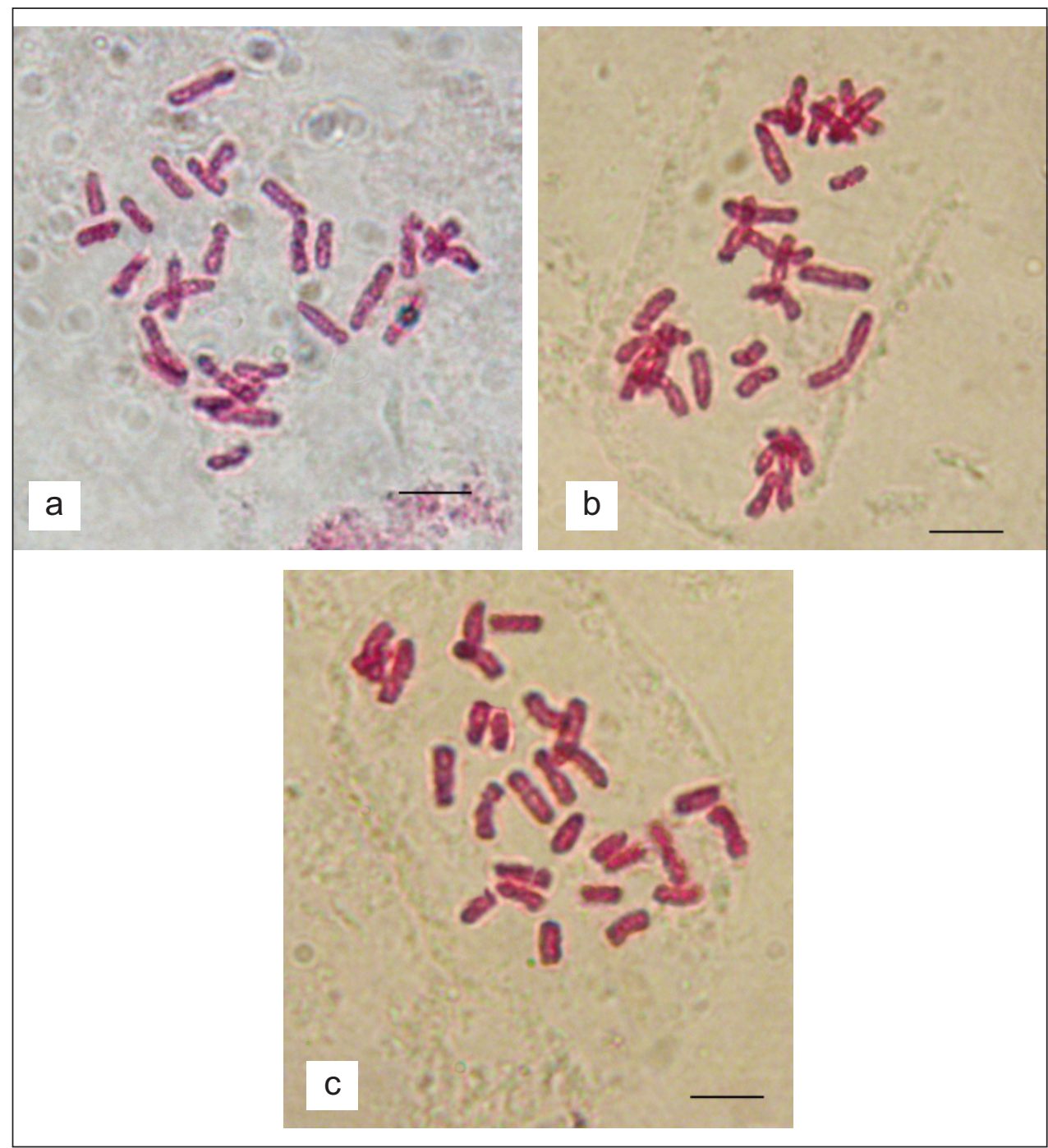

Fig. 1. Microphotographs of mitotic metaphase plates of: a, Hieracium hypochoeroides subsp. lucanicum, $2 n=3 \mathrm{x}=27 ; \mathbf{b}$, H. pallidum, $2 n=3 \mathrm{x}=27$; $\mathbf{c}$, H. schmidtii subsp. nebrodense, $2 n=3 \mathrm{x}=$ 27. - Scale bars $=10 \mu \mathrm{m}$. 
1999. Hieracium schmidtii subsp. nebrodense (Tineo ex Lojac.) Di Grist., Gottschl. \& Raimondo $-2 n=3 \mathrm{x}=27$ (Fig. 1c).

Si: Palermo, Madonie Mountains, Mt. Cavallo, $37^{\circ} 49^{\prime} 41,75^{\prime}$ N, $14^{\circ} 01$ ' 56,60” E, quartzarenitic rocks, $1.474 \mathrm{~m}$ a.s.1., 27 Jun 2012, E. Di Gristina s.n. (PAL).

Hieracium schmidtii subsp. nebrodense (Tineo ex Lojac.) Di Grist., Gottschl. \& Raimondo is a little-known endemic to Sicily and it has been recently rediscovered from the type locality after almost two centuries since its first and only collection made in 1830 in the Madonie Mountains (NC-Sicily) (Di Gristina \& al. 2016b). It is a rosulate chasmophyte belonging to the collective species $H$. schmidtii ( $H$. sect. Oreadea), which includes perennial plants, characterized by glaucous-green leaves in a basal rosette with long and rigid simple hairs at least on the leaf margins or on the surface.

The aggregate includes also the Sicilian endemic subspecies of the Madonie Mountains, H. schmidtii subsp. madoniense (syn. H. madoniense, see Raimondo \& Di Gristina 2007).

The chromosome number $2 n=3 \mathrm{x}=27$ (Fig. 1c), found here for the first time on material from its locus classicus (Mt. Cavallo, Madonie Mountains) is included in the variability $(2 n=3 \mathrm{x}=27,2 n=4 \mathrm{x}=36)$ reported for the collective species $H$. schmidtii by Sell \& West (1976), and it corresponds with the one found for H. schmidtii subsp. madoniense by Raimondo \& Di Gristina (2007).

\section{References}

Babcock, E. B. 1947: The genus Crepis. Part One. - Univ. Calif. Publ. Bot. 21: 1-197.

Braütigam, S. \& Greuter, W. 2007: A new treatment of Pilosella for the Euro-Mediterranean flora. Notulae ad floram euro-mediterraneam pertinentes No. 24. - Willdenowia 37: 123-137.

Brullo, S., Campo, G. \& Romano, S. 2005: Indagini citotassonomiche sul genere Hieracium L. (Asteraceae) in Sicilia. - Inform. Bot. Ital. 36(2): 481-485.

Chrtek J. jr., Mráz P. \& Severa M. 2004: Chromosome numbers in selected species of Hieracium s.str. (Hieracium subgen. Hieracium) in the Western Carpathians. - Preslia 76: 119-139.

—, — \& Sennikov, A. 2006. Hieracium $\times$ grofae, a rediscovered diploid hybrid from the Ukrainian Carpathians. - Biologia 61: 365-373. https://doi.org/10.2478/s11756-006-0066-0

Di Gristina, E., Geraci, A. \& Raimondo, F. M. 2005: Osservazioni citotassonomiche su popolazioni siciliane afferenti a Hieracium pallidum (Asteraceae). - Inform. Bot. Ital. 37(1): 26-27.

—, Domina, G., Gottschlich, G., Mazzola, P. \& Geraci, A. 2013: Morphological and genetic diversity within Pilosella hoppeana aggr. (Asteraceae) in Italy and taxonomic implications. - P1. Biosyst. 147(3): 788-799. https://doi.org/10.1080/11263504.2013.829880

—, Gottschlich, G. \& Raimondo, F. M. 2014a: Hieracium terraccianoi (Asteraceae), a new species endemic to the Pollino National Park (Southern Italy). - Phytotaxa 188(1): 55-60. https://doi.org/10.11646/phytotaxa.188.1.8

—, Domina, G. \& Geraci, A. 2014b: Report 1837. In: Kamari, G., Blanché, C. \& Siljak-Yakovlev, S. (eds), Mediterranean chromosome numbe rereports - 24. - Fl. Medit. 24: 283-284. https://doi: 10.7320/FlMedit24.273

—, Gottschlich, G. \& Raimondo, F. M. 2015a: Taxonomic remarks on Hieracium sartorianum var. lucanicum (Asteraceae), a little known taxon of Cilento (Campania, southern Italy). - Nordic J. Bot. 33: 465-468. http://dx.doi.org/10.1111/njb.00755 
—, — \& - 2015b: Hieracium hypochoeroides subsp. peracutisquamum (Asteraceae), a new taxon from Basilicata, southern Italy. - Ann. Bot. Fennici 52: 376-380. http://dx.doi.org/10.5735/085.052.0519

—, — \& - 2016a: Hieracium hypochoeroides subsp. cilentanum (Asteraceae), a new taxon from $\mathrm{S}$ Italy. - Phytotaxa 246(3): 192-197. https://doi.org/10.11646/phytotaxa.246.3.3

- - — \& - 2016b: Rediscovery of Hieracium nebrodense (Asteraceae), a little-known endemic of Sicily (Italy). - Phytotaxa 265(1): 59-66. https://doi.org/10.11646/phytotaxa.265.1.5

Gottschlich, G., Raimondo, F. M. \& Di Gristina, E. 2013: Hieracium pallidum subsp. aetnense (Asteraceae), a new subspecies from Sicily (Italy), with notes on the taxonomy of H. pallidum Biv. - Pl. Biosyst. 147(3): 826-831. https://doi.org/10.1080/11263504.2013.829882

Niketic M., Bareka P. \& Kamari G. 2003: Karyosystematic study of selected Hieracium (Compositae) taxa from Mt. Durmitor (Montenegro). - Bot. Chron. 16: 23-45.

Merxmüller, H. 1975. Diploide Hieracien. - Anal. Inst. Bot. Cavanilles 32: 189-196.

Mráz P., Chrtek J. jr. \& Kirschner J., 2001. Genetic variation in the Hieracium rohacsense Group. (Hieracium sect. Alpina). - Phyton 41: 269-276.

Raimondo, F. M. \& Di Gristina, E. 2007: Hieracium madoniense (Asteraceae), a new species from Sicily. - Pl. Biosyst. 141(1): 86-92. https://doi.org/10.1080/11263500601153982

Sell, P. D. \& West, C. 1976: Hieracium L. - Pp. 358-410 in: Tutin, T. G., Heywood, V. H., Burges, N. A., Moore, D. M., Valentine, D. H., Walters, S. M., Webb, D. A. (eds), Flora Europaea, 4. - Cambridge.

Addresses of the authors:

Emilio Di Gristina ${ }^{1 *}$, Gianniantonio Domina ${ }^{1} \&$ Anna Geraci²,

${ }^{1}$ Department of Agricultural, Food and Forest Sciences (SAAF), University of Palermo, Viale delle Scienze, bldg.4, 90128 Palermo, Italy. E-mails: emilio.digristina@unipa.it; gianniantonio.domina@unipa.it

${ }^{2}$ Department of Biological, Chemical and Pharmaceutical Sciences and Technologies, Via Archirafi 38, 90123 Palermo, Italy. E-mail: anna.geraci@unipa.it *Corresponding author 